\title{
The Effect of Monetary Policy on Economy Growth of WAEMU Countries
}

\author{
Franck Edouard Gnahe ${ }^{\circledR}$, Fei-Ming Huang* \\ School of Finance, Jiangxi University of Finance and Economics, Nanchang, China \\ Email: franckgnahe@jxufe.edu.cn, franckgnahe7@gmail.com, *huangfeiming@jxufe.edu.cn
}

How to cite this paper: Gnahe, F. E., \& Huang, F.-M. (2020). The Effect of Monetary Policy on Economy Growth of WAEMU Countries. Open Journal of Business and Management, 8, 2504-2523. https://doi.org/10.4236/ojbm.2020.86156

Received: September 24, 2020

Accepted: November 14, 2020

Published: November 17, 2020

Copyright $\odot 2020$ by author(s) and Scientific Research Publishing Inc. This work is licensed under the Creative Commons Attribution International License (CC BY 4.0).

http://creativecommons.org/licenses/by/4.0/

(c) (i) Open Access

\begin{abstract}
This paper examines the relationship between economic growth and monetary policy. Using panel cointegration structure for the eight West African Economic and Monetary Union (WAEMU) countries, we examine the impact of monetary policy on growth covering the period of 1988-2018. The results from estimation analysis showed that money supply and gross fixed capital formation had positive and significant impact on economic growth. The finding also shows that the real interest rate had significant effect on economic growth. The domestic credit to the private sector and the official exchange rate indicated a positive and statistically significant effect on economic growth.
\end{abstract}

\section{Keywords}

Monetary Policy, Growth, WAEMU, DOLS, FMOLS

\section{Introduction}

WAEMU countries have been an import-dependent economy faced with stagnated growth, unstable business cycles and economic fluctuation. This sometimes results in the state of unproductivity, inflation and balance of payment disequilibrium.

In the studies conducted by Folawewo and Osinubi (2006), it describes the monetary policy as a combination of measures designed to regulate the supply, the value, and the cost of money in the economy, with the expected level of economic activity.

Like any others developing countries, member Countries of West Africa Economic and Monetary Union (WAEMU) have adopted three types of public policies tools aiming at proper income distribution and allocation of resources. These tools of public policy include: monetary, fiscal and income policies. In 
WAEMU countries, the authorities have directly relied on fiscal and monetary policies as the road to obtain certain economic objective case in the management of the resource, such as macroeconomic objective including: balance of payment equilibrium, economic growth and employment.

The reason for choosing a monetary policy is the fact that it has a very serious implication for both fiscal and income policy measures; monetary policies are instruments adopted to regulate the management of the resource directly by the leaders of the WAEMU countries.

Monetary policy refers to the combination of measurements designed to regulate the value, supply and cost of money in an economy in consonance with the level of the economic activities. It can be described as the art of controlling the direction and movement of monetary and credit facilities in pursuance of stable price and economic growth in the economy. This is the case of the Central Bank of West African States CBWAS for WAEMU zone. The objective of CBWAS is to guarantee the current stability, without prejudice.

The CBWAS shall support the general economic policies adopted by the member states of monetary union, as there is no consensus among economists as to whether government intervention through the use of monetary policy will bring about economic stabilization.

This disagreement divided the economist into different schools of thought. They are the Keynesian school, the classic school, and the monetarist school. Each of them has its opinion on how variation in the monetary aggregates could impact the economic stabilization. The monetarist bases their opinions on money supply as the key factor affecting the wellbeing of the economy. They believe that an increase in the money supply will lead to an increase in the nominal demand, and where there is the excess capacity, they believe that the output will be increased. In the long-run, the monetarist position explains the increase in the money supply will be inflationary without any impact on employment, investment, and aggregate demand. Most of papers have focused largely on monetary policy neutrality in the long run and developed countries Asongu (2014). Such problems include high unemployment rate, low investment, high rate of inflation and unstable foreign exchange rate. These perceived problems are being claimed to have caused a fast decline in the economic growth of WAEMU countries. Therefore, it becomes necessary to highlight the monetary policy in WAEMU countries and examine the extension to which it has actually contributed to the economy growth.

This paper examines the effect of monetary policy on economy growth of WAEMU countries.

\subsection{Objectives of the Study}

This work has the following objectives:

- To examine the impact of the variables of money supply on WAEMU countries. 
- To explore the influence of the monetary policy of growth on WAEMU countries.

- To examine and observe the effect of monetary policy of growth considering the Gravity model.

\subsection{Research Questions}

The following questions will help to achieve the above objectives.

1) Is there any effect of the monetary policy influence output in WAEMU countries?

2) How does the official exchange rate affect the level in output?

3) What extension has of macroeconomic variables such as domestic credit to the private sector, the gross fixed capital formation and real interest rate affected the economic growth?

\section{Literature Review and Theoretical Framework}

Extensive study has been done in an attempt to establish the effect of monetary policy on the economic growth, yet with little consensus on time. Some works have confirmed limited or no effect in the monetary policy. Using an SVAR model with orthogonalized identification find little evidence of a real effect of the monetary policy in five commonwealths of independent Nations with the notable exception that interest rate has a significant impact on output (gross domestic product) in Russia, Starr (2005).

According Onyeiwu (2012) examined the impact of monetary policy on the Nigeria economy using Ordinary Least Squares (OLS) method, the result showed that monetary policy represented by money supply exerts a positive impact on GDP growth and balance of payment but negative impact on rate of inflation and concluded that Central Bank of Nigeria policy is effective in regulating the liquidity of the economy which affects some macroeconomic variables such as output, the employment and prices. It is true that these studies defect puzzling results from their analysis, however, it seems to have no ambiguous concerning the impact of monetary policy on output growth and prices developed economies as discussed by Christiano et al. (1996). There are important literature viewing the effect of monetary policy and economic variables using an econometric methodology like GMM (general method of moment) a single-equation regression among others. Most of empirical studies imposed some restrictions in the relationship between monetary policy and economic variables in order to identify policy shocks, more generally, they use forecast error variance decomposition based on Cholesky identification procedure. The exchange rate as an indicator of the monetary policy. In some studies, conducted by Adefeso and Mobolaji (2010), also investigated fiscal-monetary policy and economic growth in Central bank by employing Jabansen Maximum Likelihood Co-integration procedure, the result shows that there is a long-run relationship between economic growth, government expenditure and broad money supply (M2). Owalabi 
and Adegbite (2014) examined the effect of monetary policy on industrial growth in West Africa economy using multiple regression analysis. They analyzed the relationship between rate and industrial growth, and the observed in their findings that the variables have a significant effect on the industrial growth. Chuku (2009) examined the effect of monetary policy innovation in Nigeria, for study purposes, He used a Structural Vector Auto-Regression (SVAR) approach to trace the impact of monetary stocks on output and prices. The work also analyzed three alternative policy instruments, that is Broad Money (M2), minimum rediscount rate (MRR), and the real exchange rate (RER), the study found evidence that monetary policy innovations have both real and nominal effect on economic parameter depending on the policy variable selected.

Okoro et al. (2013) examined the effect of monetary policy outcomes on macroeconomic stability in West Africa economic. The study analyzed gross domestic credit to the private sector, net credit to government and inflation using OLS technique. The study concluded that none of the variables were significant, which suggested that using a monetary policy as a policy option may be inefficient in influencing price stability.

Chaudhry et al. (2012) investigated the long-run and short-run relationship of the monetary policy, economic growth and inflation in Pakistan using co-integration technique and ECM. They found that monetary policy variable of call money was insignificant in the short run but positively significant in the long run.

Mugume (2011) utilized the Five variables non-recursive VAR to estimate monetary transmission mechanisms in Uganda. Using broad money and three-month T-bill rate (lending rate) as proxies of monetary policy, the results showed that a shock to interest rate (91-day T-bill rate) was considered as the monetary shock and it was found that a contractionary monetary policy reduced economic growth lasting up to two quarters while innovation in broad money (M2) has no statistically significant effect on output.

Moursi and El Mossallamy (2010) analyzed monetary policy in Egypt and its effect on inflation and growth by using the Bayesian approach to estimate a dynamic stochastic general equilibrium (DSGE) model for a small closed economy. They found that the impact of a monetary policy negative shocks are relatively more significant on the output rather than on the inflation, indicating that expansionary monetary policy is capable of stimulating the economic growth without imposing too much pressure on prices.

Dele (2007) investigated the monetary and macroeconomic stability perspective of West African Monetary zone countries. The regression result indicates the monetary policy, as captured by money supply and credit to government, hurt real domestic output of these countries. The study also shows that interest rates policy had an adverse effect on GDP contrary to the theoretical expectation of an inverse relationship, and that exchange rate devaluations have no effect on the output. 
Khabo and Harmse (2005) estimated the effect of monetary policy on South Africa, using OLS and annual data. They found that money supply (M3) and inflation are significantly related to economic growth in accordance with the theory.

\subsection{Conceptual Framework}

The effect of monetary policy on economic growth has long been an important discussion in the macroeconomic theory. Monetary policy concept was defined as any policy measure designed by the government through the CBWAS to control cost price availability of credit. It also referred to as the regulation of money supply and interest rate by the CBWAS in order to control inflation and to stabilize the currency flow in an economy. Also, the Central Bank of West Africa States has a long history of monetary policy in monetary union, spanning 57 years; this experience is great in lessons learning as evidenced by the level of activities.

The proof that's inconsistent with theoretical expectations came back from totally different investigations in numerous nations is what economic expert typically refers to as puzzles, the three most typical puzzles known within the literature area unit, the liquidity puzzle and also the rate of exchange puzzle. The liquidity puzzle could be a finding that a rise financial aggregates is among a rise instead of decrease in interest rates. Whereas value the worth the value puzzle is that the finding that contractionary financial policy through positive innovations in rate appears to guide to extend instead of a decrease in price. And however most typical in open economies is that the exchanges rate puzzle that could be a finding that a rise in rate is related to depreciation (rather than appreciation) of the native domestic currency. In update studies, scientists have devised convenient ways that of eradicating these puzzles. Most of them currently follow the framework according by Lucas (1972) the united nations counseled the incorporation of national expectations within the studies of the result of monetary policy. According to Abeng (2006), it explained that monetary policy is valid just for an extremely monetized economy. If the economy isn't monetized, the efficaciousness of monetary policy is restricted. Some recent investigations that follow this approach embrace for Zhang (2009). Most of economic expert agree that within the long run the output is typically measured by gross domestic product (GDP) is fixed, such a lot of changes within the funds solely cause cost to vary, according to Koshy (2012) however within the short run as a result of cost and wages typically don't change like a shot, changes in funds will have an effect on the particular production of goods and services.

\subsection{Theory of Classical Monetarist}

The classical monetary theory is the first renowned theory of monetary policy and is enshrined in the Irving Fisher quantity theory of money QTM, which lays the foundation for the link between monetary policy and economic variables, 
which is given by the following expression $\mathrm{MV}=\mathrm{PY}$.

$\mathrm{M}$ denotes the supply of money over which the federal authority has some control, and $\mathrm{V}$ denotes the velocity of circulation which is the average number of times the currency is spent on final goods and services over the course of the year, and P denotes the price level GDP. Hence PY represents current nominal of GDP.

The equation of exchanges is identity which states that the current market value of all final goods and services (GDP) must equal the supply of money multiplied by average number of times a currency is used in transaction in a given year.

In the classical monetary theory, the first renowned theory of monetary policy is enshrined in the Ivring Fisher, which lays the foundation for the link between monetary policy (money) and macroeconomics variables. This theory, both velocity of money and output are assumed as constant, thus any increase in the quantity of money will only eventually increase prices proportionally in accordance with the quantity theory. The long run growth was only affected by real factors, and money supply has both short run and long run neutrality, the economist Gali (2008), Mankiw and Taylor (2007). According to Keynes (1936) rejected the quantity theory, both theoretically and as a tool of applied policy, in part arguing that velocity of money is unstable and not constant. QTM also assumed the absence of the trade-off between inflation and output. Keynesianism rationalized that prices are rigid and that quantity of money adjusted rapidly. Money demand was not exogenous and is dependent on income and interest rates as explained in the liquidity preference theory. The theory also assumes a positive relationship between output and interest rate, based on the liquidity preference money supply relationship, also known as the LM curve. In the basic version of the IS-LM model assumes a fixed price level; and thus, cannot be used to analyze inflation but output in the short run Hicks (1937).

\subsection{The Monetarist View of Monetary Policy}

Monetarist theory came to the fore in the 1950s, monetarist is a school of thought led by Milton Friedman. This college of though could be a fashionable variant of classical economics. The developed a subtler and relevant version of amount theory of money. Like several college of though, Friedman \& Schwartz (1963) emphasized on the availability of money because the key issue poignant the wellbeing of the economy and still, accepted the necessity for associate degree emotional financial policy to stabilize associate degree economy. He conjointly has the state, so as to push steady rate of growth, monetary resource ought to a hard and fast rate, rather than being regulated and altered by financial authority. Friedman equally argued that since money supply might be demanded for reasons other than anticipated transaction, it can be help in different forms such as money, bonds, equities, physical goods and human capital. Each form of this wealth has a unique characteristic of this its own and a different yield. In 
this effect can ultimately increase combination cash demand and expand output. The nominal rigidities in wage worth land costs imply that financial policy impact real financial gain within the short run; a rise in cash stock would have temporary increase in real output GDP and employment within the general price. Finances within the end of the day are inflationary, so the theory assumed long run monetary neutrality within the long run is inflationary. There is substantial evidence found in even recent literature to this see Bullard (1999) and Bernanke \& Mihov (1998).

\section{Empirical Framework}

\subsection{Descriptions of Variables}

Gross domestic product per capita (GDPC): of every economy is just aggregate volume everything being equal of goods and services created over determined timeframe. Gross domestic product is utilized as a proportion of economic growth in this postulation and it monetary policies on economic growth has estimated economic growth per capita term, Alfaro (2003).

Money supply (MS): As per Jha (2005) there existed a widespread criticism against adopting simple sum methods in monetary aggregation; the most important reason for this was that the simple sum procedure treated all the included monetary assets as alike in their "moneyness" and implicitly assumed that all the component assets were perfect substitutes.

Real Interest Rate (RIR): Irving Fisher in his Theory of interest in Haberler (1931) was one of the first scholars to "split" the rate: the nominal interest rate. He postulated that the nominal interest rate is approximately equal to, and is therefore comprised of the real.

Official Exchange Rate (OER): Nevertheless, the subject of the real money exchange rate should be the currency (cash). According to Vegh (2013), in monetary models, it is the currency that can appreciate or depreciate in either nominal or real terms.

Gross Fixed Capital Formation (GFCF), also called investment, is defined as acquisition of produced assets, including the production of such assets by producers for their own use, minus disposal. The relevant assets relate to assets that are intended for use in production of other goods and services for a period of more than a year.

Domestic Credit to Privat Sector (DCP): refers to financial resources provided to the private sector by financial corporations, such as through loans, purchases of nonequity securities, and trade credits and other accounts receivable, that establish a claim for repayment. For some countries these claims include credit to public enterprises.

\subsection{Data}

The main objective of the paper was to investigate the extent to which variation in broad money supply, Real interest rate, gross fixed capital formation, domes- 
tic credit to private sector, official real exchange rate has been and used to influence Gross domestic product in WAEMU economy. To evaluate the relationship between in these variables and aggregate output or GDP, multiple regression models was adopted because its simplicity to deal with log. The annual time series data were collected from 1988 to 2018. The data were collected from International Monetary Fund (IMF) and World Bank Indicator (WDI).

Multiple regression analysis of (OLS) is the estimation technique that being employed in this study to determine the effect of monetary on economy growth case of WAEMU countries.

The model copying the effect of monetary policy on economic growth case of WEMU countries, variables are determinate above with independent variables as Money supply, real interest rate, gross fixed capital formation, domestic credit to private sector, official exchange rate, while dependent variable is (GDPC) gross domestic product per capita.

\subsection{Model}

This model is based on the assumption that money supply contributes to economic growth directly thought new technologies and other inputs as well as indirectly through improving government and institutions and level of a country productivity depends on money supply, real interest rate, official exchange rate, gross fixed capital formation, and domestic credit to private sector. As the variables $\mathrm{Y}$ capture the total factor productivity effect on growth in output and it is assumed the effect of money supply on growth operates through variables GDP and the effect of monetary policy on growth also depends on the real interest rate, official exchange rate, gross fixed capital formation and domestic credit to private sector.

This econometric model is derived from a production function is which the level of a country productivity depends on money supply, real interest rate, official exchange rate, gross fixed capital formation, domestic credit to private sector and gross domestic product per capita. The model is based on endogenous growth theory, this section develops the estimating equation and draw from the literature by using the augmented function approach in investigating the interaction of effect of monetary policy on economy growth in West Africa Economic and Monetary Union economic during the period 1988 to 2018. According to analytical framework provided by Kohpaidon (2005), we can say that he gives a nation's generation a chance to be spoken to the following total production function.

The methodological approach of the relationship between monetary policy and economic growth require the implementation of rigorous economic technique. Taking into account the literature theoretical and empirical specificity of economic of WAEMU countries, we specify a econometric model that connects money supply as a capital of GDP with the rate of GDP growth, real interest rate, official exchange rate, gross fixed capital formation and domestic credit to pri- 
vate sector. For not misleading estimates of causal relation in statistical, stationary, it is necessary to resort first to preliminary statistical testing protocol.

According to the econometric methodology, we refer to model based on endogenous growth theories of Gregory Hansen (1996) procedure and Lee \& Strazicich (2001) of theoretical derivation of model approach where money supply contributes to economic growth directly through new technologies and another inputs as well through improving, infrastructure, institution and human capital.

These results will allow us to have stationary variables to determine their order of integration. And we will make the regression for an equation that will allow us to estimates parameters of our model and make different econometric tests. To assess an empirically effect of monetary policy on economic growth of WAEMU countries, specify the following basing formulation:

$$
\begin{aligned}
\ln Y_{i t}= & \alpha_{1}+\alpha_{2} \ln \mathrm{MS}_{i t}+\alpha_{3} \ln \mathrm{RIR}_{i t}+\alpha_{4} \ln \mathrm{OER}_{i t} \\
& +\alpha_{5} \ln \mathrm{DCP}_{i t}+\alpha_{6} \ln \mathrm{GFCF}_{i t}+\varepsilon_{i t}
\end{aligned}
$$

where, $Y$ is per capita of Gross Domestic Product;

MS: Money Supply;

IR: Real Interest Rate;

ER: Official Exchange Rate;

DCP: Domestic Credit to private sector;

GFCF: Gross Fixed Capital Formation;

$\varepsilon$ : Stochastic error term.

\subsection{Research Methodology}

A model is schematic representation of the theory to make analysis easier, these presentations are formal and structured but incomplete and approximate a set of real elements. All selected and defined by the template creator.

In general, model is based on theory that assumes a causal link. One of the goals it pursues is also simplify the theory check its consistency. It is well to test the validity of the theory by comparing the fact.

In econometric language, the set of questions as a model derived from the theoretical literature is called the structural form of the model. To be explicit, this form must be specified, in this section we will try to specify the model that we will study.

Employing the OLS approach, Nouri and Samimi (2011) examined the relationship between money supply and economic growth for the period 1974-2008 in Iran, hence the relation between monetary policies and economic growth can be framed by gravity model came limelight as one the analytical tool. Gravity model improved further by Aitken (1973), Anderson (1979), and Bergstrand (1985), in order to specify the gravity model in cross-sectional FMOLS and DOLS by Kao and Chiang (1999), specification explicitly will comprise of time invariant variables. Thus, specification the gravity model can stated as following function: 


$$
Y=F\left[K_{\mathrm{MS}}+K_{\mathrm{RIR}}+K_{\mathrm{OER}}+K_{\mathrm{DCP}}+K_{\mathrm{GFCF}}+E\right]
$$

where $Y$ is growth of output, $K_{\mathrm{MS}}$ is money supply, $K_{\mathrm{RIR}}$ is real interest rate, $K_{\mathrm{OER}}$ is official exchange rate, $K_{\mathrm{DCD}}$ is domestic credit to private sector, $K_{\mathrm{GFCF}}$ is gross fixed capital formation, $E$ is the overflow impact from monetary supply, $K_{\mathrm{MS}}$, $K_{\mathrm{RIR}}, K_{\mathrm{OER}}, K_{\mathrm{DCP}}$ and $K_{\mathrm{GFCF}}$ will be include of stock of capital $Y_{0}$ in next equation.

Lucas (1988) model and Romer (1994) partition in work of mechanics of economic development, $E$ is the overflow impact from MS, $\alpha$ and $\beta$ are the flexibility of the capital ( $Y$ ) separately and an allude effectiveness of production. Luca and Romer $(1988,1994)$ partition of human capital which is includes in stock of capital $\left(Y_{0}\right)$ and GDP based on productivity, besides, the rate of economic growth is influenced by the load assumption growth, the above growth determinant are augmented in Equation (3) to output the implicit equation growth:

$$
Y=F\left[y_{0}, \mathrm{MS}, \mathrm{RIR}, \mathrm{OER}, \mathrm{GFCF}, \mathrm{DCP}, \varepsilon\right]
$$

where $Y$ is growth output $y_{0}$ is a stock of capital, MS, RIR, OER, GFCF, DCP, there are factor contribution of growth, $\varepsilon$ is general error term.

A time series model comprises both longitudinal and cross-sectional data, is a dynamic dimension across space, time and variables Wooldridge (2002). In our case there are one country, 30 years data and six variables. Therefore Equation (3) is further modified to include cross sectional units time horizon explicitly, thus the dynamic cross-country growth model is given as:

$$
Y_{i t}=A F\left[y_{i t}^{\beta_{1}}, \mathrm{MS}_{i t}^{\beta_{2}}, \mathrm{RIR}_{i t}^{\beta_{3}}, \mathrm{OER}_{i t}^{\beta_{4}}, \mathrm{GFCF}_{i t}^{\beta_{5}}, \mathrm{DCP}_{i t}^{\beta_{6}}, \varepsilon_{i t}\right]
$$

where $i$ refer cross-sectional units, i.e. nation, $t$ refers to time units, of years which from 1988 to 2018 for computational comfort and less demanding comprehension, the non-linear condition is changed over straight equation through logarithmic change as follows:

$$
Y_{i t}=\beta_{0}+\beta_{1} \ln y_{i t}+\beta_{2} \mathrm{MS}_{i t}+\beta_{3} \mathrm{RIR}_{i t}+\beta_{4} \mathrm{OER}_{i t}+\beta_{5} \mathrm{GFCF}_{i t}+\beta_{6} \mathrm{DCP}_{i t}+\varepsilon_{i t}
$$

where $\beta_{0}$ is the intercept, $\beta_{1}, \beta_{2}, \beta_{3}, \beta_{4}, \beta_{4}, \beta_{6}$ are coefficient or respective explanatory variables.

The main source data are from World Development Bank, International Monetary Fund and library of Jiangxi University of Finance and Economics.

The dependent variable output is (GDPC) gross domestic product at capita price $(Y)$ and the date set utilized cover period (as per data available) from 1988 to 2018 .

\subsection{Hypotheses of the Study}

Since the expositions of the role of monetary policy in influencing macroeconomic objective case like economic growth, equilibrium in balance of payments, and price stability, monetary authorities are saddled the responsibility of using monetary policy to grow their economies. Ayodeji and Oluwole (2018) analyzed the impact of monetary policy on economic growth in Nigeria by developing a model that is able to investigate how monetary policy of the government has 
impacted economic growth through the use of multivariable regression analysis. He found a positive relationship between monetary policy and economic growth; as the result the variable money supply and interest rate had a positive effect on economic growth. Gul, Mughal and Rahim (2012) analyzed the relationship between monetary policy and growth for Pakistan. He found that monetary policy with well-adjusted policy tool such as money supply, real interest rate and exchange rate have direct correlation with growth. The study concluded that monetary policy was critical for macro stability in Pakistan. Therefore, as a result of these empirical studies, we assume that monetary policy has significant effect on economic growth in WAEMU countries. In particular, we make the following assumptions:

Ho: Real Interest rate (RIR) has a significant affect the economy growth (GDPC) in WAEMU countries

H1: These exist a positive relationship between Official Exchange rate (OER) and the level of output (GDPC) in WAEMU countries

H2: Money supply (MS) is brought directly effect on GDPC of WAEMU countries

\subsection{Empirical Procedures}

Fist, the empirical analyses started with the descriptive statistics and correlation analysis to avoid the problems of multicollinearity among the variables. As a result, the paper removed the highly correlated variables from the model before the regression analysis. Next this work carried out four-unit root tests on all the variables in order to avoid spurious results and to approve our model's specification in first difference. In particular, we employed the Lm et al. (2003) test IPS, the Augmented Dickey and Fuller (1981) ADF, and the Phillips and Peron (1988) test PP, all that assume an individual unit root process, while the test by Levin et al. (2002) LLC, follows a common unit root process. We performed these tests under the null hypothesis of non-stationary variables against the alternative hypothesis of stationary variables. Third we estimated the equation by considering cointegration test and panel test cointegration. Next, we estimated by considering various econometric techniques and selecting the most suitable from the ordinary least square OLS ignoring the countries, we investigated the robustness of the results from the static model by employing panel DOLS method standard errors on the selected model, as well as by using the indicator of countries. This technique is robust to cross-sectional dependence between the panel units by employing a nonparametric approach to estimate the standard errors that are robust to autocorrelation and cointegration. Also, Dumistrescu Hurlin (2004) proposed a similar bi variate testing procedure to Granger causality test in the panel setting. Used their testing approach takes into the heterogeneity of the regression model. The causality relationship creates a system of equation by combining the level with the de difference equation to generate valid instrument to solve the problem. 


\section{Findings and Discussions}

Data obtained from the relevant sources were prepared in Excel application and then transported to the Stata tool. According to the model specified above, the regression analysis was therefore executed to establish the relation between the variables. The result were then presented in the table.

\section{Descriptive Statistics}

This Table 1 presents a descriptive of statistics for effect of monetary policies in West African Economic and Monetary Union. The higher mean was recorded at 728.4977 , which belongs to gross domestic product per capita. As the mean is below the maximum, the standard deviation of monetary policy in handing their cost to income seems to be fairly good. The standard deviation is 25.286.357, which is quite high among the other independent variables. This depicts that spread between maximum and minimum value is fairly moderate and displayed inconsistency in gross domestic product per capita as value were varied from the highest to the lowest amount. Although the monetary policies did not show a wide gap, it can be interpreted that the monetary policy in the west African economic and monetary union is attending to improve the cost to income ratio within the year as the figure is still relevant for this case. The lowest mean belongs to real interest rate with 2.523732 and the standard deviation is 3.381313 . the findings displayed that the median of real interest rate was close to both maximum and minimum amounts, which depicted real interest rate as having the least volatile. Since the outcome of the standard deviation was very little, it indicated that the real interest rate was less affected and under control. This showed that monetary policy in west Africa economic and monetary union faced by the banking industry, which constitutes along with policy market.

The descriptive statistics of all variables from 1988 to 2018. Panel shows the results of effect of monetary policies on economy growth. The number of observations is 224 for GDPC, MS, DCP, and OER but for RIR is 104 from 1988 to 2018. The mean value of the GDPC, MS, RIR, DCP, OER, and GFCF respectively, showing that on mean 728.4977, 25.46832, 2.523732, 15.54443, 512.9627, 18.66987, respectively, over period 1988-2018. The result shows a significant variation from GDPC to GFCF, respectively 336.7369 and 7.179665.

\section{Unit Root analysis}

It important to check the order of integration of variables, LLC, IPS, ADF and PP test are used at level from first difference of each series. The results of each test are reported in Table 2 report the results of the unit root test developed by Im et al. (2003), Dickey and Fuller (1981), Phillips and Perron (1988) and Levin et al. (2002), the analysis find the variables are not stationary at the level following Im et al. (2003). The results of the test by Dickey and Fuller (1981), and Phillips and Perron (1988) show that some variables are not stationary at the level, contrary to other variables. However, the tests of Im et al. 2003, and Dickey and Fuller (1981) and Phillips and Perron (1988) indicate that all variable are statio- 
nary at the level $1 \%$ of significant. Likewise, the test of Levin et al. (2003), corroborates that all variables are stationary at the first difference. Thus, we conclude that all the variables are stationary at the first difference at $1 \%$ and $5 \%$ level of significance. Therefore, our models using the first difference operator are appropriate for avoiding spurious estimates for all the four tests in 1\% and 5\% significance level. Thus, the data for all the variables in equation 5 appear as I(1) based on the LLC, IPS, ADF, and PP tests with 5 lags, implying the presence of long-run characteristics in each variables, which in turn enables cointegration tests.

Table 1. Descriptive statistics.

\begin{tabular}{ccccccc}
\hline & GDPC & MS & RIR & DCP & OER & GFCF \\
\hline Mean & 728.4977 & 25.46832 & 2.523732 & 15.54443 & 512.9627 & 18.66987 \\
Median & 621.6062 & 23.56715 & 3.307383 & 14.36305 & 511.5524 & 18.70480 \\
Maximum & 1616.169 & 68.86858 & 9.019543 & 41.15628 & 733.0385 & 48.39674 \\
Minimum & 322.7779 & 6.546494 & -7.695814 & 0.402581 & 264.6918 & 5.885067 \\
Std. Dev. & 336.7369 & 9.410625 & 3.381313 & 7.776245 & 121.0085 & 7.179665 \\
Skewness & 0.900516 & 1.146672 & -0.788519 & 0.760266 & -0.537662 & 0.706236 \\
Kurtosis & 2.591300 & 5.214959 & 3.617496 & 3.804608 & 3.103944 & 3.981008 \\
Jarque-Bera & 31.83366 & 94.87766 & 12.42953 & 27.62119 & 10.69864 & 27.60292 \\
Probability & 0.000000 & 0.000000 & 0.002000 & 0.000001 & 0.004751 & 0.000001 \\
Sum & 163183.5 & 5704.904 & 262.4681 & 3481.951 & 112851.8 & 4182.050 \\
Sum Sq. Dev. & 25286357 & 19748.85 & 1177.627 & 13484.81 & 3206830. & 11495.11 \\
Observations & 224 & 224 & 104 & 224 & 220 & 224 \\
\hline
\end{tabular}

Note: $O b s$ and $S t d D e v$ denote the number of observation and standard deviation of the variables, respectively, whereas Min and Max indicate the number and maximum value values of the variables, Mean represents the mean of the variables over the period 1988-2018 for the 8 countries.

Table 2. Unit Root.

\begin{tabular}{|c|c|c|c|c|c|c|c|c|}
\hline \multirow{2}{*}{ Variables } & \multicolumn{2}{|c|}{ LLC } & \multicolumn{2}{|c|}{ IPS } & \multicolumn{2}{|c|}{$\mathrm{ADF}$} & \multicolumn{2}{|c|}{ PP } \\
\hline & Level & First. Diff & Level & First. diff & Level & First. diff & Level & First. diff \\
\hline $\operatorname{lnGDPC}$ & $\begin{array}{l}-0.157 \\
(0.437)\end{array}$ & $\begin{array}{c}-6.284^{* * *} \\
(0.000)\end{array}$ & $\begin{array}{c}2.984 \\
(0.998)\end{array}$ & $\begin{array}{c}-8.165^{* * *} \\
(0.000)\end{array}$ & $\begin{array}{c}8.454 \\
(0.934)\end{array}$ & $\begin{array}{c}96.331^{* * *} \\
(0.000)\end{array}$ & $\begin{array}{c}5.663 \\
(0.991)\end{array}$ & $\begin{array}{c}120.605^{* * *} \\
(0.000)\end{array}$ \\
\hline $\ln M S$ & $\begin{array}{c}2.267 \\
(0.988)\end{array}$ & $\begin{array}{c}-14.768^{* * *} \\
(0.000)\end{array}$ & $\begin{array}{c}2.380 \\
(0.991)\end{array}$ & $\begin{array}{c}-13.535^{* * *} \\
(0.000)\end{array}$ & $\begin{array}{l}11.531 \\
(0.775)\end{array}$ & $\begin{array}{c}148.124^{* * *} \\
(0.000)\end{array}$ & $\begin{array}{l}13.287 \\
(0.651)\end{array}$ & $\begin{array}{c}154.614^{* * *} \\
(0.000)\end{array}$ \\
\hline RIR & $\begin{array}{c}-4.153^{* * *} \\
(0.000)\end{array}$ & $\begin{array}{c}-8.882^{* * *} \\
(0.000)\end{array}$ & $\begin{array}{c}-2.774^{* * *} \\
(0.002)\end{array}$ & $\begin{array}{c}-6.367^{* * *} \\
(0.000)\end{array}$ & $\begin{array}{c}32.593^{* * *} \\
(0.008)\end{array}$ & $\begin{array}{c}65.329^{* * *} \\
(0.000)\end{array}$ & $\begin{array}{c}40.135^{* * *} \\
(0.000)\end{array}$ & $\begin{array}{c}102.904^{* * *} \\
(0.000)\end{array}$ \\
\hline $\ln \mathrm{DCP}$ & $\begin{array}{c}0.783 \\
(0.783)\end{array}$ & $\begin{array}{c}-8.638^{* * *} \\
(0.000)\end{array}$ & $\begin{array}{c}1.524 \\
(0.936)\end{array}$ & $\begin{array}{c}-9.728^{* * *} \\
(0.000)\end{array}$ & $\begin{array}{c}7.991 \\
(0.0 .949)\end{array}$ & $\begin{array}{c}112.044^{* * *} \\
(0.000)\end{array}$ & $\begin{array}{c}7.452 \\
(0.963)\end{array}$ & $\begin{array}{c}131.292^{* * *} \\
(0.000)\end{array}$ \\
\hline $\operatorname{lnOER}$ & $\begin{array}{c}-8.945^{* * *} \\
(0.000)\end{array}$ & $\begin{array}{c}-3.437^{* * *} \\
(0.000)\end{array}$ & $\begin{array}{c}-8.755^{* * *} \\
(0.000)\end{array}$ & $\begin{array}{c}-3.420^{* * *} \\
(0.000)\end{array}$ & $\begin{array}{c}101.555^{* * *} \\
(0.000)\end{array}$ & $\begin{array}{c}37.276^{* * *} \\
(0.001)\end{array}$ & $\begin{array}{c}29.510^{* * *} \\
(0.000)\end{array}$ & $\begin{array}{c}122.652^{* * *} \\
(0.000)\end{array}$ \\
\hline $\operatorname{lnGFCF}$ & $\begin{array}{l}-0.912 \\
(0.180)\end{array}$ & $\begin{array}{c}-13.507^{* * *} \\
(0.000)\end{array}$ & $\begin{array}{l}-1.457^{*} \\
(0.072)\end{array}$ & $\begin{array}{c}-14.035^{* * *} \\
(0.000)\end{array}$ & $\begin{array}{l}25.529^{*} \\
(0.061)\end{array}$ & $\begin{array}{c}161.300^{* * *} \\
(0.000)\end{array}$ & $\begin{array}{l}19.108 \\
(0.263)\end{array}$ & $\begin{array}{c}172.164^{* * *} \\
(0.000)\end{array}$ \\
\hline
\end{tabular}

Note: Im et al. (2003); ADF Dickey and Fuller (1981); PP: Phillips and Perron (1988); LLC Levin et al. (2002). The null hypothesis Ho: I (0) assumes a unit root process at the level, whereas Ho: I (1) supposes a unit root process at the first difference. ${ }^{* *} p<0.01,{ }^{* *} p<0.05$ and ${ }^{*} p<0.1$. 


\section{Cointegration test analysis}

In the Table 3 and Table 4 The cointegration test and panel cointegration tests can analysis the long-run equilibrium between variables. This work have been proved that all the variables are stationary in the same order. Therefore, this study further conducts by Pedroni tests (1999). The cointegration relationship of Pedroni test (2004), the test are described by inner scale and group scale according to the different test strength of each statistic, so it present seven (7) statistics. The Pedroni test is based on the general panel fixed effect model. In this paper Pedron framework provides cointegration tests based on seven (7) residual-based statistic Pedroni (1999). For the 7 statistics, the panel v-statistic, panel rho-statistic, panel PP-statistic are based on the within dimension.

Table 3. Pedroni Residual Cointegration test.

\begin{tabular}{|c|c|c|c|c|c|c|}
\hline \multirow[t]{2}{*}{ Methods } & \multicolumn{3}{|l|}{ Within-dimension } & \multicolumn{3}{|c|}{ Between-dimension } \\
\hline & Test & Statistic & Prob & Test & Statistic & Prob \\
\hline \multirow[t]{4}{*}{ Pedroni (1999) } & Panel v-Stat & 0.344977 & 0.3651 & Group rho-Stat & 3.596513 & 0.9998 \\
\hline & Panel rho-stat & 2.211832 & 0.9865 & Group PP-Stat & -4.324792 & 0.0000 \\
\hline & Panel PP-stat & -3.772725 & 0.0001 & Group ADF-Stat & -4.542495 & 0.0010 \\
\hline & Panel ADF-Stat & -3.325116 & 0.0004 & & & \\
\hline \multirow[t]{4}{*}{ Pedroni (2004) } & Panel v-Stat & -1.450848 & 0.9266 & & & \\
\hline & Panel rho-stat & 2.263391 & 0.9882 & & & \\
\hline & Panel PP-stat & -5.183565 & 0.0000 & & & \\
\hline & Panel ADF-Stat & -5.141132 & 0.0000 & & & \\
\hline
\end{tabular}

Note: Null hypothesis, no cointegration, Trend assumption; no deterministic intercept or trend, automatic lag length selection.

Table 4. Panel cointegration test.

\begin{tabular}{|c|c|c|c|c|c|c|}
\hline \multirow[t]{2}{*}{ Methods } & \multicolumn{3}{|l|}{ Within-dimension } & \multicolumn{3}{|c|}{ Between-dimension } \\
\hline & Test & Statistic & Prob & Test & Statistic & Prob \\
\hline \multirow[t]{4}{*}{ Pedroni (1999) } & Panel v-Stat & -1.116905 & 0.8680 & Group rho-Stat & 3.584474 & 0.9998 \\
\hline & Panel rho-stat & 2.104577 & 0.9823 & Group PP-Stat & -3.748138 & 0.0001 \\
\hline & Panel PP-stat & -4.189722 & 0.0000 & Group ADF-Stat & -3.088071 & 0.0010 \\
\hline & Panel ADF-Stat & -3.883944 & 0.0001 & & & \\
\hline \multirow[t]{4}{*}{ Pedroni (2004) } & Panel v-Stat & -0.840725 & 0.7997 & & & \\
\hline & Panel rho-stat & 2.350623 & 0.9906 & & & \\
\hline & Panel PP-stat & -3.642206 & 0.0001 & & & \\
\hline & Panel ADF-Stat & -3.353254 & 0.0004 & & & \\
\hline
\end{tabular}

Note: Null hypothesis, no cointegration, Trend assumption; no deterministic intercept or trend, automatic lag length selection. 
The Pedroni residual Cointegration tests presents contradictory results for all the variables in Table 3 . For all the variables, the statistically significant $t$-statistic of Pedroni test indicates. Due to the heterogeneity allowed for the Pedroni tests, the presence of long-run equilibrium relationship among variables which turn enables the estimation, using DOLS and FMOLS.

Table 3 and Table 4 report both the within between dimension panel co-integration test statistics. These statistics are based on averages of the individual autoregressive coefficients associated with the unite root tests of the residuals for each country in the panel. These results suggest that the null of co-integration cannot be rejected at the significance level of $5 \%$ so there exist at least one probability values are less than $5 \%$. The evidence suggests that in all panel data sets there is a co-integration long run relationship between monetary policy and economic growth.

In this Table 5, the Kao residual cointegration test also show us for every case of opportunity cost at $5 \%$ level of significance we reject null hypothesis of no cointegration and every case p-value 0.0000 which is highly significance it gives a strong evidence that all the variables has long-run relationship.

\section{Result of the regression analysis}

The model was estimated using a multiple regression, in terms of the sign and magnitude of the coefficient which signify the impact of monetary policies on economic growth case of WAEMU countries; It was observed from the result of the effect of monetary policies on economic growth case of WAEMU countries from 1988 to 2018 . We considered the pooled OLS model, with a view to the model of cointegration vector, however, the two different methods, DOLS and FMOLS. Each of this method provides three different estimators namely 1, 2, 3 mean. The pooled DLS estimator is proposed by Kao (1999) where the augmented cointegration regression allows the short run dynamics to be cross section specific. By allowing heterogenous long run variance. And the pooled FMOLS estimator is the extension of Phillips and Hansen (1990). FMOLS estimator offered by Phillips and Moon (1999) which provides the estimator after correcting determinant components in regressor. In order to allow the different long run variance across the section for heterogenous panel, Pedroni (1999) and Kao (1999) proposed FMOLS models. Finally, the group estimator developed Phillips and Hansen (1990) and Pedroni (2004) is derived by averaging the individual country cross section DOLS and FMOLS estimates.

Table 5. Kao Residual cointegration test.

\begin{tabular}{ccc}
\hline ADF & t-Statistic & Prob \\
\cline { 2 - 3 } & -4.745011 & 0.0000 \\
\hline Residual variance & 0.000640 & 0.0000 \\
HAC variance & 0.000610 & 0.0000 \\
\hline
\end{tabular}

Note: Null hypothesis, no cointegration, Trend assumption; no deterministic trend, automatic lag length selection. ADF: Augmented Dickey Fuller. 
Table 6 contains the estimation results of short run relationship between on macroeconomic variables, it is evident that the elasticity of different variable with respect to income in West Africa economic and monetary countries. For instance, on panel of variables shows an interesting income on the relation between monetary policies and growth. The money supply show in group (1) 0.056 and group (3) 0.098 mean significant and statistically positive at the $5 \%$ level of significance. The R-squared was observed to be significant in all the case thus the effect of monetary policies in West Africa economic and monetary union can be argued as necessary and normal. The relationship between monetary policies and growth of their economies were positive based on past information, these imply that the effect of monetary policies in WAEMU countries were productive in supporting growth.

Table 7 contains the result of cointegration relationship between macroeconomic variable improvement measured by effect of monetary policies on growth. The elasticity coefficient of money supply, real interest rate, domestic credit to private, official exchange rate and gross fixed capital formation was observed significant and statistically positive at 5\% level of significance. This imply that the effect of monetary policies in west Africa economic and monetary union were productive during the period under review. Definitely, that policies have intense effect on growth.

\section{Analysis to the Dumitrescu Hurlin panel causality test}

In Table 8 as explained in the literature on panel Granger causality tests (Dumitrescu \& Hurlin 2012) when the result of the model showing GDP as an dependent variables, the panel statistics explaining that individuals forming the panel under the null hypothesis do not have overall cointegration relationship significant at the level 1\%. The Dumitrescu \& Hurlin (2012) approach stated that there are directional causalities between money supply, real interest rate, official exchange rate, domestic credit to private sector, and gross fixed capital formation. Thus, the policy that affects one of them, in order to have a good and appropriate policies, they must simultaneously achieve reduction in policies market and without trade. The recommendation based on our finding is that market policy should prioritize developing the policies without impact on the growth.

Table 6. Results of the estimation using the panel DOLS method.

\begin{tabular}{cccc}
\hline Variables & $(1)$ & $(2)$ & $(3)$ \\
\hline $\ln \mathrm{MS}$ & $0.056(0.249)$ & & $0.098^{\star *}(0.026)$ \\
RIR & & $2.97 \mathrm{E}-05(0.985)$ & $4.26 \mathrm{E}-05(0.976)$ \\
$\operatorname{lnDCP}$ & $0.139^{* * *}(0.000)$ & $0.098^{* * *}(0.000)$ & $0.048^{*}(0.061)$ \\
$\operatorname{lnOER}$ & $0.168^{* * *}(0.000)$ & $0.313^{* * *}(0.000)$ & $0.279^{* * *}(0.000)$ \\
$\ln$ GFCF & $0.038(0.269)$ & $0.158^{* * *}(0.000)$ & $0.140^{* * *}(0.000)$ \\
R-squared & 0.958 & 0.994 & 0.994 \\
Observations & 220 & 100 & 100 \\
\hline
\end{tabular}

Note: DOLS represent the OLS model, respectively. ${ }^{* *} p<0.001,{ }^{* *} p<0.05$ and ${ }^{\star} p<0.1$. 
Table 7. Results of the estimation using the panel FMOLS method.

\begin{tabular}{cccc}
\hline Variables & $(1)$ & $(2)$ & $(3)$ \\
\hline $\ln \mathrm{MON}$ & $0.047^{* *}(0.023)$ & & $0.085^{* * *}(0.000)$ \\
$\mathrm{RIR}$ & & $0.0002(0.798)$ & $0.0003(0.431)$ \\
$\ln \mathrm{NCP}$ & $0.157^{* * *}(0.000)$ & $0.106^{* * *}(0.000)$ & $0.059^{* * *}(0.000)$ \\
$\operatorname{lnOER}$ & $0.170^{* * *}(0.000)$ & $0.333^{* * *}(0.000)$ & $0.292^{* * *}(0.000)$ \\
$\operatorname{lnGFCF}$ & $0.037^{* * *}(0.009)$ & $0.157^{* * *}(0.000)$ & $0.148^{* * *}(0.000)$ \\
R-squared & 0.959 & 0.994 & 0.995 \\
Observations & 212 & 92 & 92 \\
\hline
\end{tabular}

Note: FMOLS represent the OLS model, respectively. ${ }^{* * *} p<0.001,{ }^{* *} p<0.05$ and ${ }^{\star} p<0.1$.

Table 8. Paiwise Dumitrescu Hurlin panel Causality test.

\begin{tabular}{cccc}
\hline Null hypothesis & W-Stat & Zbar-Stat & Prob \\
\hline LNMS does not homogeneously cause LNGDPC & 2.41750 & 2.26794 & 0.0233 \\
LNGDPC does not homogeneously cause LNMS & 2.21761 & 1.92620 & 0.0541 \\
RIR does not homogeneously cause LNGDPC & 3.80118 & 3.09345 & 0.0020 \\
LNGDPC does not homogeneously cause RIR & 1.93093 & 0.79347 & 0.4275 \\
LNDCP does not homogeneously cause LNGDPC & 1.85608 & 1.30813 & 0.1908 \\
LNGDPC does not homogeneously cause LNDCP & 7.40819 & 10.8000 & 0.0000 \\
LNOER does not homogeneously cause LNGDPC & 3.16529 & 3.52637 & 0.0004 \\
LNGDPC does not homogeneously cause LNOER & 0.33142 & -1.29697 & 0.0000 \\
LNGFCF does not homogeneously cause LNGDPC & 5.33377 & 7.25356 & $4 . \mathrm{E}-13$ \\
LNGDPC does not homogeneously cause LNGFCF & 2.11615 & 1.75274 & 0.0796 \\
\hline
\end{tabular}

Note: Computed by the Authors.

\section{Conclusion and Policy Recommendations}

This paper examined the effect of monetary policies on economic growth case of WAEMU countries. The study covers the period of 1988 to 2018, using multiple regression analysis. This study conjointly evaluates the impact of financial policy variables inside the institutional framework and basic theoretical model on economic expansion. The result shows that Ivoirian economic growth is responsive to some of the macroeconomic variables, such as exchange rate. Furthermore, the result suggests that money supply, real interest rate, official exchange rate, domestic credit to private sector, gross fixed capital formation and gross domestic product per capita may been affected by change in economic activity, which influenced the desire to hold currency for productive purpose. This study notes that monetary policy implementation in the developing country like WAEMU countries faces additional challenges that are not present in developed economies, such as fiscal dominance and the treat of currency substitution. This work concludes and suggests that the inability of effectiveness of monetary policies to 
maximize its objective most time is as a result of shortcoming of the policy intuitional used in West African (Franc zone) economy which limits its contribution to growth even though monetary policy had brought impressive contribution over the years, and suggests that monetary policy measure should be well be coordinated so that the desire behavioral changes in the real sector will be achieved. Policy adopted should be limited to having power capacity of economy. Pursing the policies with the aim of improving monetary policy, exchange rate, gross fixed capital formation would have more effect on WAEMU economic growth than isolating them. However, the quality of institution and governance alone may not be sufficient. To ensure sustainable growth in WAEMU countries, increased gross fixed capital formation and increased foreign direct investment as well as adequate investment in human capital also take place. Arguably, due to monetary policy to have desired effect on the real WAEMU countries economy, which is the fundamental objective case of monetary policy, it is essential to improve the level of economic activity and capital market.

\section{Author Contribution}

All authors contributed equally to all aspects of this research.

\section{Funding}

This research has not received external funding.

\section{Conflicts of Interest}

The authors declare no conflicts of interest regarding the publication of this paper.

\section{References}

Abeng, M. O. (2006). Financial Sector Reform Outcomes in Nigeria: A Quantitative Evaluation. CBN Bullion, 30, 53-69.

Adefeso, H. A., \& Mobolaji, H. I. (2010). The Fiscal-Monetary Policy and Economic Growth in Nigeria: Further Empirical Evidence. Pakistan Journal of Social Sciences, 7, 137-142. https://doi.org/10.3923/pjssci.2010.137.142

Aitken, N. D. (1973). The Effect of the EEC and EFTA on European Trade; a Temporal Cross-Section Analysis. American Economic Review, 63, 881-892.

Anderson, J. (1979). The Theoretical Foundation for Gravity Equation. American Economic Review, 69, 106-116. https://doi.org/10.1353/hjr.2010.0076

Asongu, S. A. (2014). A Note on the Long-Run Neutrality of Monetary Policy: New Empirics. European Economics Letters, 3, 1-6. https://doi.org/10.2139/ssrn.2493400

Ayodeji, A., \& Oluwole, A. (2018). Impact of Monetary Policy on Economic Growth in Nigeria. Open Access Library Journal, 5, e4320. https://doi.org/10.4236/oalib.1104320

Bergstrand, J. (1985). The Gravity Equation in International Trade: Some Microeconomic Foundation and Empirical Evidence. Review of Economics and Statistics, 67, 474-481. https://doi.org/10.2307/1925976

Bernanke, B. S., \& Mihov, I. (1998). Measuring Monetary Policy. The Quarterly Journal of 
Economics, 113, 869-902. https://doi.org/10.1162/003355398555775

Bullard, J. (1999). Testing Long-Run Neutrality Propositions: Lessons from the Recent Research. Review, Federal Reserve Bank of St. Louis, 81, 57-78. https://doi.org/10.20955/r.81.57-78

Chaudhry, I. S., Qanber, Y., \& Farooq, F. (2012). Monetary Policy, Inflation and Economic Growth in Pakistan: Exploring the Co-Integration and Causality Relationships. Pakistan Journal of Commerce and Social Science, 6, 332-347.

Christiano, L. J., Eichenbaum, M., \& Evans, C. L. (1996). The Effects of Monetary Policy Shocks: Evidence from the Flow of Funds. The Review of Economics and Statistics, 78, 16-34.

Chuku, C. A. (2009). Measuring the Effects of Monetary Policy Innovations in Nigeria. African Journal of Accounting, Economics, Finance and Banking Research, 5, 141-153.

Dele, B. E. (2007). Monetary Policy and Economic Performance of West African Monetary Zone Countries. Munich Personal RePEc Archive Paper No. 4308.

Dickey, D., \& Fuller, W. (1981). Likelihood Ratio Statistics for Autoregressive Time Series with Unit Root. Econometrica, 49, 1057-1072. https://doi.org/10.2307/1912517

Dumitrescu, E., \& Hurlin, C. (2012). Testing for Ganger Non-Causality in Heterogeneous Panel. Economic Journal, 10, 271-248.

Folawewo, A. O., \& Osinubi, T. S. (2006). Monetary Policy and Macroeconomic Instability in Nigeria: A Rational Expectation Approach. Journal of Social Sciences, 12, 93-100. https://doi.org/10.1080/09718923.2006.11978375

Friedman, M., \& Schwartz, A. (1963). Money and Business Cycles. Review of Economics and Statistics, 45, 32-64. https://doi.org/10.2307/1927148

Gali, J. (2008). Monetary Policy, Inflation and Business Cycle: An Introduction to the New Keynesian Framework. Oxfordshire: Princeton University Press.

Gul, H., Mughal, K., \& Rahim, D. S. (2012). Linkage between Monetary Instruments and Economic Growth. Universel Journal of Management and Social Sciences, 2, 69-67.

Haberler, G. (1931). Irving Fisher's “Theory of Interest”. The Quarterly Journal of Economics, 45, 499-516. https://doi.org/10.2307/1883901

Hicks, J. R. (1937). Mr. Keynes and the "Classics": A Suggested Interpretation. Econometrica, 5, 147-159. https://doi.org/10.2307/1907242

Im, K. S., Pesaran, M. H., \& Shin, Y. (2003). Testing for Unit Roots in Heterogeneous Panels. Journal of Econometrics, 115, 53-74. https://doi.org/10.1016/S0304-4076(03)00092-7

Jha, R. (2005). The Political Economy of Recent Economic Growth in India. In R. Jha (Ed.), Economic Growth, Economic Performance and Welfare in South Asia (pp. 28-51). Houndmills: Palgrave Macmillan. https://doi.org/10.1057/9780230520318

Kao (1999). Spurious Regression and Residual Based Tests for Cointegration in Panel Data. Journal of Econometrics, 90, 1-44.

Kao, C., \& Chiang, M.-H. (1999). On the Estimation and Inference of a Cointegrated Regression in Panel Data. https://doi.org/10.2139/ssrn.1807931

Keynes, J. M. (1936). The General Theory of Employment, Interest and Money. London: Macmillan.

Khabo, V., \& Harmse, C. (2005). The Impact of Monetary Policy on Economic Growth of Small Open Economy: The Case of South Africa. South African Journal of Economic and Management Sciences, 8, a1201. https://doi.org/10.4102/sajems.v8i3.1201

Koshy, M. (2012). Monetary Policy: Stabilizing Prices and Output. Finance and Devel- 
opment, International Monetary Fund.

Lee, J., \& Strazicich, M. C. (2001). Break Point Estimation and Spurious Rejections with Endogenous Unit Root Tests. Oxford Bulletin of Economics and Statistics, 63, 535-558. https://doi.org/10.1111/1468-0084.00234

Levin, A., Lin, C.-F., \& Chu, C.-S. J. (2002). Unit Root Tests in Panel Data: Asymptotic and Finite-Sample Properties. Journal of Econometrics, 108, 1-24. https://doi.org/10.1016/S0304-4076(01)00098-7

Lucas, R. E. (1972). Expectations and Neutrality of Money. Journal of Economic Theory, 4, 103-124. https://doi.org/10.1016/0022-0531(72)90142-1

Lucas, R. E. (1988). On the Mechanics of Economics Development. Journal of Monetary Economics, 22, 3-42. https://doi.org/10.1016/0304-3932(88)90168-7

Mankiw, G. N., \& Taylor, M. P. (2007). Macroeconomics. Basingstoke: Palgrave Macmillan.

Moursi, T. A., \& El Mossallamy, M. (2010). Monetary Policy Analysis with New Keynesian Model for Egypt. Information and Decision Support Center (IDSC) of Egyptian Cabinet Working Paper.

Mugume, A. (2011). Monetary Transmission Mechanisms in Uganda. Bank of Uganda Working Paper. http://www.bou.or.ug

Nouri, M., \& Samimi, A. J. (2011). The Impact of Monetary Policy on Economic Growth in Iran. Middle-East Journal of Scientific Research, 9, 740-743.

Okoro, O. S. (2013). Impact of Monetary Policy on Nigeria Economic Growth. Prime Journal of Social Sciences, 2, 195-199.

Onyeiwu, C. (2012). Monetary Policy and Economy Growth of Nigeria. Journal of Economics and Sustainable Development, 3, 7.

Owalabi, A. U., \& Adegbite, T. A. (2014). Impact of Monetary Policy on Industrial Growth in Nigeria. International of Academic Research in Business and Social Sciences, 4, 18-31.

Pedroni, P. (1999). Critical Values for Cointegration Tests in Heterogeneous Panels with Multiple Regressors. Oxford Bulletin of Economics and Statistics, 61, 653-670. https://doi.org/10.1111/1468-0084.61.s1.14

Pedroni, P. (2004). Panel Cointegration Asymptotic and Finite Sample Properties of Pooled Time Serie Tests with an Application too PP Hypothesis. Econometric Theory, 20, 597-625. https://doi.org/10.1017/S0266466604203073

Phillips, P. C. B., \& Hansen, B. E. (1990). Statistical Inference in Instrumental Variables Regression with I(1) Processes. Review of Economic Studies, 57, 99-125. https://doi.org/10.2307/2297545

Phillips, P. C. B., \& Pierre, P. (1988). Testing for a Unit Root in Time Series Regression. Biometrika, 75, 335-346.

Romer, P. M. (1994). The Origins of Endogenous Growth. Journal of Economic Perspectives, American Association, 8, 3-22.

Starr, M. A. (2005). Does Money Matter in the CIS? Effect of Monetary Policy on Output and Prices. Journal of Comparative Economics, 33, 441-461. https://doi.org/10.1016/j.jce.2005.05.006

Wooldridge, J. M. (2002). Econometric Analysis of Cross-Section and Panel Data. Cambridge, MA: MTT Press.

Zhang, W. (2009). China's Monetary Policy: Quantity versus Price Rules. Journal of Macroeconomics, 31, 473-484. https://doi.org/10.1016/j.jmacro.2008.09.003 